УДК 634.8:581.177

DOI 10.30679/2219-5335-2021-4-70-102-114

ЭФФЕКТИВНОСТЬ

ПРИМЕНЕНИЯ ПРЕПАРАТОВ

БЕНЗИХОЛ И ЭТИХОЛ

ПРИ ВЫРАЩИВАНИИ

ОЗДОРОВЛЁННЫХ IN VITRO

МИКРОЧЕРЕНКОВ

ВИНОГРАДА

Цаценко Нионила Николаевна

канд. с.-х. наук

ведущий научный сотрудник

отдела биотехнологии

e-mail: tsatsenko.n@fnac.center

Браткова Любовь Гавриловна канд. биол. наук

ведущий научный сотрудник

отдела биотехнологии

e-mail: I.bratkova@fnac.center

Макаров Константин Анатольевич

научный сотрудник

отдела биотехнологии

e-mail:makarov.ka@bk.ru

Мащенко Марина Николаевна

научный сотрудник

отдела биотехнологии

e-mail: maschenko.marina2013@yandex.ru

Федеральное государственное

бюджетное научное учреждение

«Северо-Кавказский федеральный

научный аграрный центр»,

Михайловск, Россия

Исследования проводились в 2019 г в ФГБНУ «Северо- Кавказский ФНАЦ». Цель исследований - определение эффективности применения различных концентраций препаратов Бензихол и Этихол в твердой питательной среде для ускорения роста и развития оздоровленных in vitro микрочеренков винограда при клональном размножении. Приводятся результаты исследований
UDC 634.8: 581.177

DOI 10.30679/2219-5335-2021-4-70-102-114

\section{EFFECTIVENESS \\ OF USE BENZYCHOL \\ AND ETHYCHOL \\ PREPARATIONS IN GROWING \\ OF IMPROVED IN VITRO \\ MICRO-CUTTINGS \\ OF GRAPES}

Tsatsenko Nionila Nikolaevna

Cand. Agr. Sci.

Leading Research Associate

of Biotechnology Department

e-mail: tsatsenko.n@fnac.center

Bratkova Lyubov Gavrilovna

Cand. Biol. Sci.

Leading Research Associate

of Biotechnology Department

e-mail: I.bratkova@fnac.center

Makarov Konstantin Anatolyevich

Research Associate

of Biotechnology Department

e-mail: makarov.ka@bk.ru

Mashchenko Marina Nikolaevna

Research Associate

of Biotechnology Department

e-mail: maschenko.marina2013@yandex.ru

Federal State Budgetary

Scientific Institution

«North Caucasus Federal

Scientific Agrarian Center»,

Mikhailovsk, Russia

Studies were conducted in 2019

in the North Caucasus FSAC.

The aim of the research is to determine the effectiveness of the use of various concentrations of Benzichol and Etichol preparations in a solid nutrient medium to accelerate the growth and development of in vitro improved micro-cuttings of grapes during clonal propagation. The results of studies on the influence 
по изучению влияния новых синтетических препаратов, обладающих фиторегуляторной, стресспротекторной, ауксиновой, ретардантной, и антивирусной активностью, применяемых в очень низких дозах, которые стимулируют и ускоряют рост и развитие оздоровленных in vitro микрочеренков винограда. В опыте был использован среднеранний сорт

Альминский. Исследования показали, что добавление фиторегуляторов, стресспротекторов Бензихола и Этихола в твердую питательную среду по Мурасиге и Скуга, для выращивания оздоровленных in vitro микрочеренков винограда среднераннего сорта Альминский, в изученных концентрациях $\left(1 \times 10^{-7}, 1 \times 10^{-9}\right.$ и $\left.1 \times 10^{-11} \mathrm{M}\right)$ не способствовало ускорению процесса образования и роста корней у оздоровленных микрочеренков винограда. При этом применение Бензихола в концентрациях $1 \times 10^{-7}$ и $1 \times 10^{-9} \mathrm{M}$, напротив, привело к существенному замедлению корнеобразования у растений. Добавление в питательную среду препаратов Бензихол и Этихол в минимальной концентрации $1 \times 10^{-11} \mathrm{M}$ оказало стимулирующее действие на формирование междоузлий, через 20 суток количество междоузлий приходящееся в среднем на 1 растение, увеличилось относительно контроля на 0,5-0,7 шт. При дальнейшем росте растений через 30 суток отмеченная выше тенденция сохранилась, хотя разность с контролем уменьшилась до 0,3 шт. Это свидетельствует о возможности использования данных препаратов в целях повышения объёмов производства высококачественного однородного посадочного материала, свободного от вирусов, а в дальнейшем и к размножению здоровых саженцев, которые необходимы для закладки плантаций винограда.

Ключевые слова: ВИНОГРАД, IN VITRO, СОРТ АЛЬМИНСКИЙ, БЕНЗИХОЛ, ЭТИХОЛ, МИКРОЧЕРЕНКИ, МЕЖДОУЗЛИЯ of new synthetic preparations, that offering phytoregulatory, stress-protective, auxin, retardant, and antiviral activity, used in very low doses, which stimulate and accelerate the growth and development of in vitro improved micro-cuttings of grapes are presented.

The middle-early Alminskiy variety was used in the experiment.

Studies have shown that the addition of phytoregulators and stress-protectors Benzichol and Etihol to the solid nutrient medium according to Murashige and Skoog, for growing in vitro improved micro-cuttings of middle-early Alminskiy variety, at studied concentrations $\left(1 \times 10^{-7} ; 1 \times 10^{-9}\right.$ and $\left.1 \times 10^{-11} \mathrm{M}\right)$ did not contribute to the acceleration of the root formation and growth in improved grapes micro-cuttings. At the same time, the use of Benzichol at concentrations of $1 \times 10^{-7}$ and $1 \times 10^{-9}$, on the contrary, led to a significant slowdown in root formation in plants. The addition of Benzichol and Etihol preparations to the nutrient medium at a minimum concentration of $1 \times 10^{-11} \mathrm{M}$ had a stimulating effect on the formation of internodes, after 20 days the average number of internodes on 1 plant increased up 0.5-0.7 pcs relative to the control. With the further growth of plants after 30 days, the trend noted above remained, although the difference with control decreased to 0.3 pcs. It indicates the possibility of using these preparations in order to increase the production of high-quality homogeneous virus-free planting material, and later to reproduce healthy young plants, which are necessary for establishing of vineyards.

Key words: GRAPES, IN VITRO, ALMINSKIY VARIETY, BENZYCHOL, ETICHOL, MICRO-CUTTINGS, INTERNODES 
Введение. Закладка новых промышленных виноградников с использованием высокопродуктивных оздоровленных клонов позволит обеспечить дальнейшее развитие отрасли виноградарства в Ставропольском крае. Для этого необходимо заложить суперэлитные маточники перспективных сортов, которые в настоящее время отсутствуют.

Ставропольский край занимает 4-е место в России по площадям и валовому сбору винограда. В крае возделывается более 80 наименований сортов винограда отечественной и зарубежной селекции. Ставрополье является одним из ведущих регионов промышленного виноградарства в России с полным технологическим циклом - от выращивания саженцев до выпуска готовой продукции.

Актуальной проблемой отрасли виноградарства является вопрос оптимизации сортимента и формирования генофонда сортов винограда с высоким потенциалом качественных составляющих, а также обновление посадок со снижением их себестоимости. Главная причина медленного внедрения перспективных сортов заключается в остром дефиците сертифицированного посадочного материала винограда. Повышение эффективности отрасли возможно за счет использования методов ускоренного размножения оздоровленных in vitro новых и дефицитных сортов. Переход отрасли на производство высших категорий качества посадочного материала через культуру in vitro будет способствовать дальнейшему повышению долговечности и продуктивности перспективных сортов винограда. Для ускоренного производства востребованного посадочного материала эффективен метод микроклонального размножения in vitro благодаря высокому коэффициенту размножения. Использование технологии микроклонального размножения позволяет сократить сроки внедрения новых сортов в производство, по сравнению с традиционными методами в 4-5 раз, поскольку дает возможность круглый год выращивать растения в контролируемых условиях, в том числе 
те сорта, которые плохо укореняются обычным способом. Микрочеренкование одиночного побега, полученного от введения в культуру меристемы, позволяет производить генетически стабильный материал без опасности повышения изменчивости и отклонения от сортовых признаков. Закладка промышленных виноградников оздоровленным материалом дает возможность продлить продуктивную эксплуатацию таких насаждений и повысить урожайность на 30,0-40,0 \% [1-9].

Микрочеренкование винограда может иметь значение в размножении высококачественного посадочного материала и способствовать формированию высоких урожаев винограда при оптимизации физиологических процессов, которые можно регулировать с помощью различных стимуляторов роста и развития растений, таких как Бензихол и Этихол. Бензихол и Этихол - стресспротекторы-фиторегуляторы нового поколения разработаны в Институте физиологически активных веществ РАН и ООО «Инновационный центр ТАХИАТ» под руководством заслуженного деятеля науки РФ профессора Р.Г. Гафурова [10-18].

Цель работы - оценить эффективность применения различных концентраций препаратов Бензихол и Этихол в твердой питательной среде для ускорения роста и развития оздоровленных микрочеренков винограда при клональном размножении в условиях in vitro.

Объекты и методы исследований. Исследования проводились на базе лаборатории сельскохозяйственной биотехнологии ФГБНУ «СевероКавказский ФНАЦ» в 2019 г. в соответствии с «Методическими рекомендациями по микроклональному размножению винограда» [19-20]. Достоверность полученных данных оценивалась с помощью дисперсионного метода математической статистики и программы AgCStat-Excel.

Изучали фиторегуляторы-стресспротекторы Бензихол и Этихол. Данные препараты относятся к новой группе регуляторов роста и разви- 
тия растений и в малых дозах стимулируют важнейшие физиолого-биохимические процессы в размножаемых растениях. Степень эффективности влияния фиторегуляторов- стресспротекторов на укоренение, оздоровленных in vitro пробирочных растений винограда определяли на зеленых черенках технического среднераннего сорта Альминский в сегменте производства высококачественных вин. Данный сорт используется для производства экологически чистых соков, столовых и десертных красных вин. Сорт выведен в НИВиВ «Магарач» и обладает генетически обусловленной устойчивостью к биотическим (филлоксера, милдью, оидиум, серая гниль) и абиотическим (мороз, засуха) факторам среды. Урожайность до 140 ц/га, сахаронакопление 30 г/100 см³. В Ставропольском крае сорт районируется в Левокумском районе.

Полученные in vitro мериклоны из апикальной меристемы сорта Альминский и размноженные путем черенкования пробирочных растений, размещали на питательной среде с разной концентрацией Бензихола и Этихола. Изучение влияния препаратов с разной концентрацией на рост и развитие черенков винограда проводилось по схеме, представленной в таблице 1. Раннее нами было выявлено, что более высокие концентрации препаратов $1 \times 10^{-3} \mathrm{M}$ и $1 \times 10^{-5} \mathrm{M}$ оказывают отрицательное действие на развитие черенков, поэтому в данных исследованиях принята наиболее высокая концентрация $1 \times 10^{-7} \mathrm{M}$.

Таблица 1 - Схема опыта, 2019 г.

\begin{tabular}{|c|c|c|}
\hline $\begin{array}{c}\text { Сорт } \\
\text { винограда }\end{array}$ & Препарат & $\begin{array}{c}\text { Концентрация препарата } \\
\text { в питательной среде }\end{array}$ \\
\hline \multirow{2}{*}{ Альминский } & Бензихол & $\begin{array}{l}\text { 1. } 0 \text { (контроль); 2. } 1 \times 10^{-7} \mathrm{M} ; \\
\text { 3. } 1 \times 10^{-9} \mathrm{M} ; \text { 4. } 1 * 10^{-11} \mathrm{M}\end{array}$ \\
\hline & Этихол & $\begin{array}{l}\text { 1. } 0 \text { (контроль); 2. } 1 \times 10^{-7} \mathrm{M} \text {; } \\
\text { 3. } 1 \times 10^{-9} \mathrm{M} ; \text { 4. } 1 \times 10^{-11} \mathrm{M}\end{array}$ \\
\hline
\end{tabular}

Модельной системой для оценки эффективности данных препаратов служили черенки пробирочных растений винограда, развивающихся в строго контролируемых условиях культуры in vitro (рис. 1). 

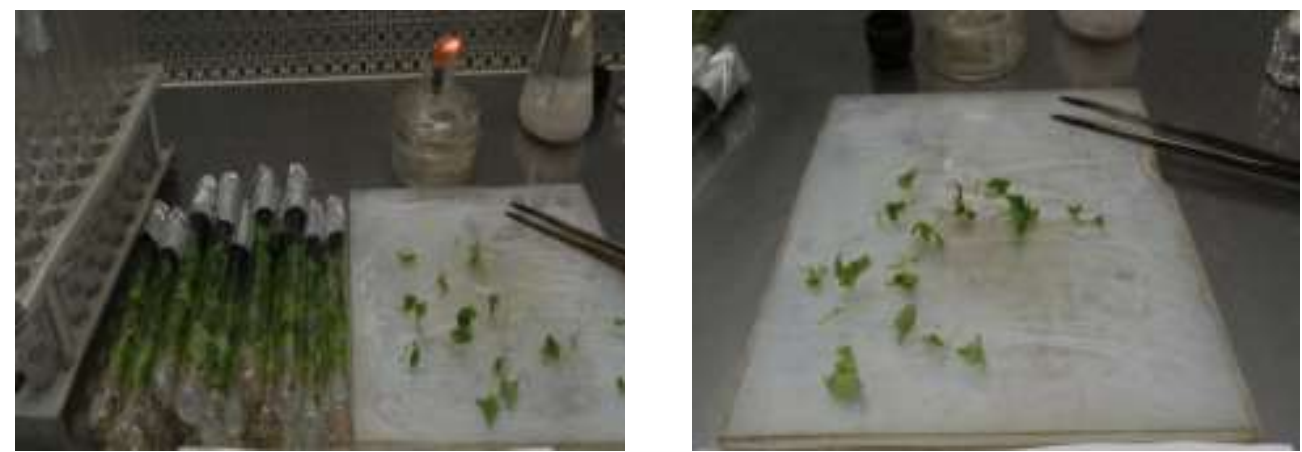

Рис. 1. Внешний вид пробирочных растений и черенков винограда перед посадкой

Черенок длиной в одно междоузлие высаживали в пробирки на агаризованную питательную среду для укоренения Н-1, с основой по Мурасиге и Скуга, в опытные варианты добавляли препараты Бензихол и Этихол в дозах $\mathbf{1} \times 10^{-7} \mathrm{M}, \mathbf{1} \times 10^{-9} \mathrm{M}, \mathbf{1} \times \mathbf{1 0}^{-11} \mathrm{M}$. Посадку черенков проводили в ламинарном боксе, высаживали 100 пробирок в 3-х кратной повторности. Далее растения инкубировали в культуральной комнате при освещенности 2,5-3,0 тысячи люкс, 16 часов дневной при температуре $23-24{ }^{\circ} \mathrm{C}$ и 8 часов ночной фотопериоды. Наблюдения за растениями проводили в основные морфогенетические периоды их развития - 10, 20 и 30-е сутки (рис. 2). Определяли линейные размеры растений, в том числе корней, подсчитывали число корешков рост междоузлий и стеблей на каждом растении.

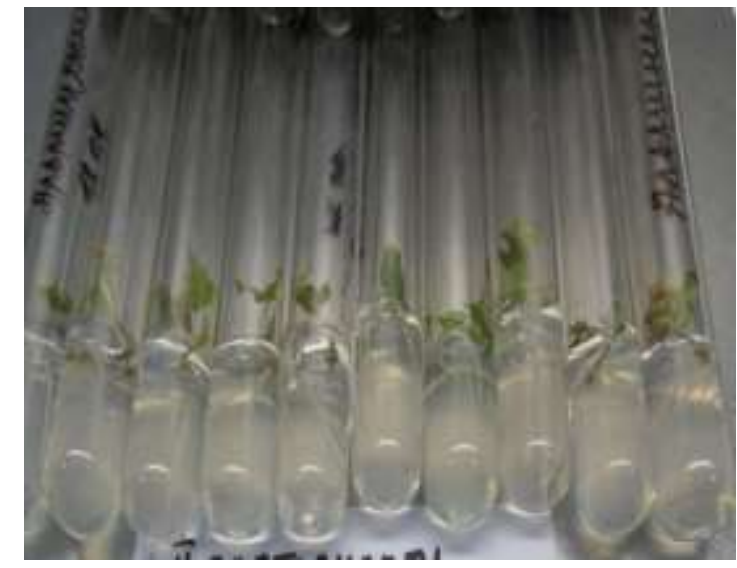

a

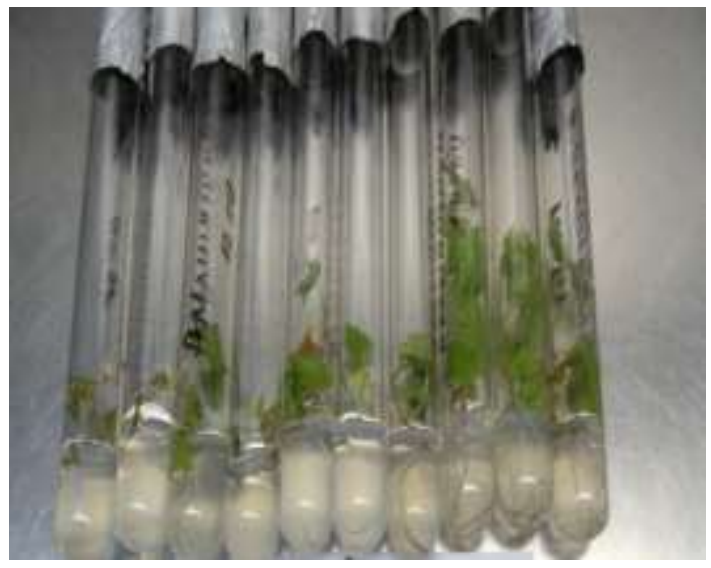

б

Рис. 2. Растения винограда в опыте через 10 дней (а) и через 20 дней (б) 
Обсуждение результатов. Влияние фиторегуляторов-стресспротекторов Бензихол и Этихол на рост и развитие оздоровленных in vitro микрочеренков винограда в первую очередь оценивалось по скорости и мощности формирования корневой системы растений, что выражалось в количестве новообразованных корней на 10-ые сутки, а также в динамике роста корней на 10-ые, 20-ые и 30-тые сутки после посадки их на питательную среду в пробирки.

Подсчёт числа корней пробирочных растений через 10 суток после проведения процедуры микроклонального размножения оздоровлённых микрочеренков винограда показал, что введение в питательную среду растворов Бензихола и Этихола не привело к увеличению количества корней независимо от их концентрации (табл. 2).

Таблица 2 - Влияние концентрации препаратов Бензихол и Этихол на формирование корней растений винограда через 10 суток после посадки микрочеренков в пробирки, шт.

\begin{tabular}{|c|c|c|c|c|}
\hline \multirow{2}{*}{$\begin{array}{c}\text { Препарат } \\
\text { (фактор А) }\end{array}$} & \multirow{2}{*}{$\begin{array}{c}\text { Степень } \\
\text { разведения препарата } \\
\text { (фактор В) }\end{array}$} & \multirow{2}{*}{$\begin{array}{c}\text { Количество } \\
\text { корней }\end{array}$} & \multicolumn{2}{|c|}{ Разность по фактору } \\
\hline & & & A & B \\
\hline \multirow{4}{*}{ Бензихол } & 0 & 3,3 & - & - \\
\hline & $10^{-7}$ & 1,7 & - & $-1,6$ \\
\hline & $10^{-9}$ & 0,9 & - & $-2,4$ \\
\hline & $10^{-11}$ & 2,5 & - & $-0,8$ \\
\hline \multirow{4}{*}{ Этихол } & 0 & 3,4 & 0,1 & - \\
\hline & $10^{-7}$ & 3,5 & 1,8 & 0,1 \\
\hline & $10^{-9}$ & 2,0 & 1,1 & $-1,4$ \\
\hline & $10^{-11}$ & 3,3 & 0,8 & $-0,1$ \\
\hline \multicolumn{2}{|c|}{$\mathrm{HCP}_{05}$ по фактору } & & 0,46 & 0,65 \\
\hline \multicolumn{2}{|c|}{$\mathrm{HCP}_{05}$ по опыту } & 0,93 & & \\
\hline
\end{tabular}

При этом применение препарата Бензихол оказало даже угнетающее действие на интенсивность процесса корнеобразования, что выразилось в достоверном снижении среднего количества корней у одного растения на 0,8-2,4 шт или 24-73 \% относительно контроля (без препарата). Наименьший отрицательный эффект влияния Бензихола на рост корней в первые десять суток после клонирования микрочеренков винограда отмечен при использовании препарата с максимальной степенью разведения $\mathbf{1} \times \mathbf{1 0}^{-11} \mathbf{M}$ 
В этот же период (через 10 суток) действие обоих препаратов негативно сказалось не только на количестве, но и на длине корней растений (табл. 3).

Таблица 3 - Влияние концентрации препаратов Бензихол и Этихол на динамику роста и развития корней микрочеренков винограда, см, 2019 г.

\begin{tabular}{|c|c|c|c|c|c|c|c|c|c|c|}
\hline \multirow{4}{*}{$\begin{array}{c}\text { Препарат } \\
\text { (фактор А) }\end{array}$} & \multirow{4}{*}{$\begin{array}{c}\text { Степень } \\
\text { разведения } \\
\text { препарата } \\
\text { (фактор В) }\end{array}$} & \multicolumn{9}{|c|}{ Период наблюдений } \\
\hline & & \multicolumn{3}{|c|}{ через 10 суток } & \multicolumn{3}{|c|}{ через 20 суток } & \multicolumn{3}{|c|}{ через 30 суток } \\
\hline & & \multirow[t]{2}{*}{ длина } & \multicolumn{2}{|c|}{$\begin{array}{c}\text { разность } \\
\text { по фактору }\end{array}$} & \multirow{2}{*}{ длина } & \multicolumn{2}{|c|}{$\begin{array}{c}\text { разность } \\
\text { по фактору }\end{array}$} & \multirow{2}{*}{ длина } & \multicolumn{2}{|c|}{$\begin{array}{c}\text { разность } \\
\text { по фактору }\end{array}$} \\
\hline & & & $\mathrm{A}$ & $\mathrm{B}$ & & A & B & & A & B \\
\hline \multirow{4}{*}{ Бензихол } & 0 & 0,59 & - & - & 2,52 & - & - & 3,89 & - & - \\
\hline & $10^{-7}$ & 0,32 & - & $-0,27$ & 1,67 & - & $-0,85$ & 2,95 & - & $-0,94$ \\
\hline & $10^{-9}$ & 0,08 & - & $-0,51$ & 1,40 & - & $-1,12$ & 3,22 & - & $-0,67$ \\
\hline & $10^{-11}$ & 0,62 & - & 0,03 & 3,02 & - & 0,50 & 4,85 & - & 0,96 \\
\hline \multirow{4}{*}{ Этихол } & 0 & 0,77 & 0,18 & - & 2,68 & 0,16 & - & 4,55 & 0,66 & - \\
\hline & $10^{-7}$ & 0,45 & 0,13 & $-0,32$ & 3,28 & 1,61 & 0,60 & 4,87 & 1,92 & 0,32 \\
\hline & $10^{-9}$ & 0,59 & 0,51 & $-0,18$ & 3,12 & 1,72 & 0,44 & 4,58 & 1,36 & 0,03 \\
\hline & $10^{-11}$ & 0,55 & $-0,7$ & $-0,22$ & 3,12 & 0,1 & 0,44 & 4,93 & 0,08 & 0,38 \\
\hline \multicolumn{2}{|c|}{$\mathrm{HCP}_{05}$ по фактору } & & 0,10 & 0,15 & & 0,40 & 0,57 & & 0,56 & $\mathrm{~F}_{\phi}<\mathrm{F}_{\mathrm{T}}$ \\
\hline \multicolumn{2}{|c|}{$\mathrm{HCP}_{05}$ по опыту } & 0,21 & & & 0,82 & & & 1,15 & & \\
\hline
\end{tabular}

Под влиянием Бензихола данный показатель в сравнении с контролем уменьшился на 0,27-0,51 см или на 46-86 \%, Этихола - на 0,18-0,32 см (23-42 \%). Исключение составил вариант с добавлением в питательную среду раствора Бензихола с наименьшей концентрацией $\left(1 \times 10^{-11} \mathrm{M}\right)$, которая не оказала существенного влияния на длину корней пробирочных растений. Исходя из вышесказанного можно заключить, что в первые 10 суток после клонирования оздоровленных микрочеренков винограда in vitro изучаемые препараты угнетающе воздействовали на процессы образования (Бензихол) и роста корней (Бензихол и Этихол). Во второй срок наблюдений (через 20 суток) минимальная длина корней (1,40-1,67 см) наблюдалась лишь при использовании Бензихола в наиболее высоких концентрациях $-1 \times 10^{-7}$ и $1 \times 10^{-9} \mathrm{M}$. Во всех других вариантах опыта длина корней соответствовала или была выше уровня контроля $(2,52-2,68$ см) на 0,44-0,60 cм или на 16-22\%. Через 30 суток основные тенденции по влиянию препаратов на рост корней, отмеченные в более ранний период, сохранились. 
Таким образом, добавление фиторегуляторов-стресспротекторовБензихола и Этихола в питательную среду в изученных концентрациях $\left(1 \times 10^{-7} ; 1 \times 10^{-9}\right.$ и $\left.1 \times 10^{-11} \mathrm{M}\right)$ не способствовало ускорению процесса образования и роста корней у оздоровленных микрочеренков винограда. При этом применение Бензихола в концентрациях $1 \times 10^{-7}$ и $1 \times 10^{-9} \mathrm{M}$, напротив, привело к существенному замедлению корнеобразования у растений.

Для увеличения количества оздоровленного посадочного материала винограда наряду с ускорением роста корневой системы большое значение имеет интенсивность развития стебля, определяемая количеством образующихся междоузлий. В первый срок наблюдений (через 20 суток) длина стебля пробирочных растений варьировала в пределах от 0,38 до 0,89 см и, как следует из данных таблицы 4, изучаемые препараты не оказали какоголибо положительного влияния на эту величину.

Таблица 4 - Влияние концентрации препаратов Бензихол и Этихол на длину стебля микрочеренков винограда в зависимости от времени роста, см, 2019 г.

\begin{tabular}{|c|c|c|c|c|c|c|c|}
\hline \multirow{4}{*}{$\begin{array}{c}\text { Препарат } \\
\text { (фактор А) }\end{array}$} & \multirow{4}{*}{$\begin{array}{c}\text { Степень } \\
\text { разведения } \\
\text { препарата } \\
\text { (фактор В) }\end{array}$} & \multicolumn{6}{|c|}{ Период наблюдений } \\
\hline & & \multicolumn{3}{|c|}{ через 20 суток } & \multicolumn{3}{|c|}{ через 30 суток } \\
\hline & & \multirow{2}{*}{$\begin{array}{l}\text { длина } \\
\text { стебля }\end{array}$} & \multicolumn{2}{|c|}{$\begin{array}{c}\text { разность } \\
\text { по фактору }\end{array}$} & \multirow{2}{*}{$\begin{array}{l}\text { длина } \\
\text { стебля }\end{array}$} & \multicolumn{2}{|c|}{$\begin{array}{c}\text { разность } \\
\text { по фактору }\end{array}$} \\
\hline & & & A & B & & A & B \\
\hline \multirow[t]{4}{*}{ Бензихол } & 0 & 0,38 & - & - & 1,52 & - & - \\
\hline & $10^{-7}$ & 0,44 & - & 0,06 & 1,10 & - & $-0,42$ \\
\hline & $10^{-9}$ & 0,45 & - & 0,07 & 1,11 & - & $-0,41$ \\
\hline & $10^{-11}$ & 0,56 & - & 0,18 & 1,65 & - & 0,13 \\
\hline \multirow[t]{4}{*}{ Этихол } & 0 & 0,80 & 0,42 & - & 1,80 & 0,28 & - \\
\hline & $10^{-7}$ & 0,65 & 0,21 & $-0,15$ & 1,98 & 0,88 & 0,18 \\
\hline & $10^{-9}$ & 0,67 & 0,22 & $-0,13$ & 1,30 & 0,19 & $-0,50$ \\
\hline & $10^{-11}$ & 0,89 & 0,33 & 0,09 & 2,20 & 0,55 & 0,40 \\
\hline \multicolumn{2}{|c|}{$\mathrm{HCP}_{05}$ по фактору } & & 0,13 & $\mathrm{~F}_{\phi}<\mathrm{F}_{\mathrm{T}}$ & & 0,28 & 0,39 \\
\hline \multicolumn{2}{|c|}{$\mathrm{HCP}_{05}$ по опыту } & 0,26 & & & 0,57 & & \\
\hline
\end{tabular}

На 30 -е сутки наблюдений в результате действия Этихола в минимальной концентрации $1 \times 10^{-11} \mathrm{M}$ произошло достоверное увеличение средней длины стеблей в сравнении с контролем на 0,40 см или $22 \%$. Применение Бензихола в двух наиболее высоких концентрациях $\left(1 \times 10^{-7}\right.$ и $\left.1 \times 10^{-9} \mathrm{M}\right)$, 
Плодоводство и виноградарство Юга России № 70(4), 2021 г.

напротив вызвало замедление роста растений и снижение длины стебля на 0,41-0,42 см или 27-28\%.

Добавление в питательную среду препаратов Бензихол и Этихол в минимальной концентрации $\left(1 \times 10^{-11} \mathrm{M}\right)$ оказало стимулирующее действие на формирование междоузлий. Под их влиянием через 20 суток количество междоузлий, приходящееся в среднем на 1 растение, увеличилось относительно контроля на 0,5-0,7 шт. (табл. 5). При дальнейшем росте растений (через 30 суток) отмеченная выше тенденция сохранилась, хотя разность с контролем уменьшилась до 0,3 шт.

Таблица 5 - Влияние препаратов Бензихол и Этихол на количество междоузлий микрочеренков винограда в зависимости от периода роста, шт

\begin{tabular}{|c|c|c|c|c|c|c|c|}
\hline \multirow{4}{*}{$\begin{array}{c}\text { Препарат } \\
\text { (фактор А) }\end{array}$} & \multirow{4}{*}{$\begin{array}{c}\text { Степень } \\
\text { разведения } \\
\text { препарата } \\
\text { (фактор В) }\end{array}$} & \multicolumn{6}{|c|}{ Период наблюдений } \\
\hline & & \multicolumn{3}{|c|}{ через 20 суток } & \multicolumn{3}{|c|}{ через 30 суток } \\
\hline & & \multirow{2}{*}{\begin{tabular}{|c|} 
количество \\
междоуз- \\
лий \\
\end{tabular}} & \multicolumn{2}{|c|}{$\begin{array}{c}\text { разность } \\
\text { по фактору }\end{array}$} & \multirow{2}{*}{$\begin{array}{l}\text { количество } \\
\text { междоузлий }\end{array}$} & \multicolumn{2}{|c|}{$\begin{array}{c}\text { разность } \\
\text { по фактору }\end{array}$} \\
\hline & & & A & $\mathrm{B}$ & & A & B \\
\hline \multirow[t]{4}{*}{ Бензихол } & 0 & 1,1 & - & - & 2,5 & - & - \\
\hline & $10^{-7}$ & 1,3 & - & 0,2 & 2,0 & - & $-0,5$ \\
\hline & $10^{-9}$ & 1,3 & - & 0,2 & 2,3 & - & $-0,2$ \\
\hline & $10^{-11}$ & 1,8 & & 0,7 & 2,8 & & 0,3 \\
\hline \multirow[t]{4}{*}{ Этихол } & 0 & 1,6 & 0,5 & - & 2,9 & 0,4 & - \\
\hline & $10^{-7}$ & 1,6 & 0,3 & 0,0 & 2,9 & 0,9 & 0,0 \\
\hline & $10^{-9}$ & 1,8 & 0,5 & 0,2 & 2,9 & 0,6 & 0,0 \\
\hline & $10^{-11}$ & 2,1 & 0,3 & 0,5 & 3,2 & 0,4 & 0,3 \\
\hline \multicolumn{2}{|c|}{$\mathrm{HCP}_{05}$ по фактору } & & 0,3 & 0,4 & & 0,3 & $\mathrm{~F}_{\phi}<\mathrm{F}_{\mathrm{T}}$ \\
\hline \multicolumn{2}{|c|}{$\mathrm{HCP}_{05}$ по опыту } & 0,5 & & & 0,7 & & \\
\hline
\end{tabular}

Bbывоbы. Как показали наши исследования, добавление фиторегуляторов-стресспротекторов Бензихол и Этихол в питательную среду для выращивания оздоровленных in vitro микрочеренков винограда среднераннего сорта Альминский определило наличие положительного эффекта на рост и развитие растений в концентрациях, не превышающих $1 \times 10^{-11} \mathrm{M}$. Влияние более высоких концентраций Этихола $\left(1 \times 10^{-7} \mathrm{M}\right.$ и $\left.1 \times 10^{-9} \mathrm{M}\right)$ оказалось недостоверным, а использование Бензихола в этих концентрациях привело даже 
к существенному замедлению роста и развития пробирочных растений в течение всего периода наблюдений - 30 суток.

Введение препаратов Бензихол и Этихол в питательную среду в концентрациях $1 \times 10^{-7} \mathrm{M} ; 1 \times 10^{-9} \mathrm{M}$ и $1 \times 10^{-11} \mathrm{M}$ не способствовало активизации процесса образования и роста корней у пробирочных растений винограда.

Положительное действие Этихола в концентрации $1 \times 10^{-11} \mathrm{M}$ проявилось в ускорении роста стебля и формировании дополнительного количества междоузлий, Бензихола - лишь в образовании побегов. Под влиянием Этихола через 30 суток после посадки микрочеренков в пробирки, длина стебля увеличилась относительно контроля на 0,40 см или на $22 \%$.

В результате применения данных препаратов количество междоузлий, приходящееся в среднем на 1 растение, через 20 суток увеличилось относительно контроля на 0,5-0,7 шт.

Влияние фиторегуляторов-стресспротекторов на количество междоузлий свидетельствует о возможности использования данных препаратов в целях увеличения объёмов производства высококачественного безвирусного посадочного материала винограда.

\section{Литература}

1. Браткова Л.Г., Цаценко Н.Н. Клональное микроразмножение винограда // Достижения науки и техники АПК. 2015. № 6 (Т. 29). С. 49-52.

2. Цаценко Н.Н., Браткова Л.Г., Малыхина А.Н., Мащенко М.Н. Выращивание мериклонов винограда в нестерильных условиях [Электронный ресурс] // Плодоводство и виноградарство Юга России. 2017. № 43(1). С. 30-41. URL: http://journalkubansad.ru/pdf/17/01/04.pdf. (дата обращения: 07.07.2021).

3. Браткова Л.Г., Малыхина А.Н., Цаценко Н.Н., Мащенко М.Н. Приёмы адаптации мериклонов винограда к условиям in vivo [Электронный ресурс] // Плодоводство и виноградарство Юга России. 2015. № 34 (4). С. 14-29. URL:http:// jornalkubansad.ru/pdf/17/01/04.pdf. (дата обращения: 17.10.2019).

4. Дорошенко Н.П. Повышение регенерационной способности меристем при оздоровлении винограда от вирусной инфекции // Материалы региональной конференции «Перспективы внедрения современных биотехнологических разработок для повышения эффективности сельскохозяйственного производства». Ставрополь, 2000. 72 с.

5. Bowers J.E., Boursiquot J.M, This P., Chu K., Johansson H., Meredith C.P. Histological genetics parentage of Chardonnay, Camay, and other wine grapes of northeastern France. Science 285:1562-1565; 1999. 
6. Stamp J.A., Meredith C.P. Somatic embryogenesis from leaves and anthers of grapevine // Scientia Hort. - 1988. - 35. - P. 235-250.

7. Зленко В.А. Размножение оздоровленного посадочного материала винограда // Садоводство и виноградарство Юга России. 2005. № 1. С. 21-23.

8. Медведева Н.И., Поливара Н.В., Трошин Л.П. Особенности микроклонального размножения интродуцентов и клонов винограда // Науч. журн. КубГАУ. 2008. № 40 (06). C. $137-155$.

9. Упадышев М.Т. Вирусные болезни и современные методы оздоровления плодовых и ягодных культур: автореф. дис. ... д-ра с.-х. наук : 06.01.07 / Упадышев Михаил Тарьевич. Москва, 2011. 47 с.

10. Гафуров Р. Зеленая революция по-русски // Агрохимия НИОКР, химический журнал. Декабрь 2003-январь 2004. С. 32-34.

11. Гафуров Р.Г. Стресспротекторы-фиторегуляторы нового поколения - шанс для инновационного развития в Республике Татарстан // Agriculture. 2008. № 2. Р. 60-62.

12. Котова 3.П., Гафуров Р.Г. Биологическая эффективность стресспротекторовфиторегуляторов бензихол и этихол при выращивании безвирусного картофеля в почвенно-климатических условиях северной зоны земледелия России // Теоретические и прикладные проблемы АПК. 2020. № 3. C. 3-8. DOI 10/32935/2221-7312-2020-45-2-3-8

13. Bajguz A., Hayat S. Effect of brassinosteroids on the plant responses to environmental stresses // Plant Physiol. Biochem. 2009. V/47/ P. 1-8.

14. Mitteler R. Oxidative stress, antioxidants and stress tolerance // Trends Plant Sci. 2002.V.7, 405-409.

15. Ulmasov T., et al. IAA Proteins Re-press Expression of Reporter Genes Containing Natural and Highly Active Synthetic Auxin Response Elements // Plant Cell. 1997. Vol. 9. P. 1963-1971.

16 Savaldi-Goldstein S. et al. New auxin analogs with growth-promoting effects in intact plants reveal a chemical strategy to improvehormone delivery // PNAS. 2008. Vol. 105. No39. P. 15190-15195.

17. Reiser V., Raitt D.C., Saito H. Yeast osmosensor Sln1 and plant cytokinin receptor Cre1 respond to changes in turgor pressure // J. Cell Biol. - 2003. - 161. - P. 1035-1040.

18. Hayashi K. et al. Unrevealed structural requirements for auxin-like molecules by theoretical and experimental evidences // Phytochemistry. 2009. Vol. 70. Issue. 2. P. 190-197.

19. Методические рекомендации по клональному микроразмножению винограда / П.Я. Голодрига [и др.]. Ялта, 1986. 56 с.

20. Медведева Н.И., Поливара Н.В., Трошин Л.П. Методические рекомендации по микроклональному размножению винограда in vitro // Научный журнал КубГау. 2010. № 65 (08) С. 314-326.

\section{References}

1. Bratkova L.G., Cacenko N.N. Klonal'noe mikrorazmnozhenie vinograda // Dostizheniya nauki i tekhniki APK. 2015. № 6 (T. 29). S. 49-52.

2. Cacenko N.N., Bratkova L.G., Malyhina A.N., Mashchenko M.N. Vyrashchivanie meriklonov vinograda $\mathrm{v}$ nesteril'nyh usloviyah [Elektronnyj resurs] // Plodovodstvo i vinogradarstvo Yuga Rossii. 2017. № 43(1). S. 30-41. URL: http://journalkubansad.ru/pdf/17/01/04.pdf. (data obrashcheniya: 07.07.2021).

3. Bratkova L.G., Malyhina A.N., Cacenko N.N., Mashchenko M.N. Priyomy adaptacii meriklonov vinograda $\mathrm{k}$ usloviyam in vivo [Elektronnyj resurs] // Plodovodstvo i vinogradarstvo Yuga Rossii. 2015. № 34 (4). S. 14-29. URL:http: // jornalkubansad.ru/pdf/17/01/04.pdf. (data obrashcheniya: 17.10.2019). 
4. Doroshenko N.P. Povyshenie regeneracionnoj sposobnosti meristem pri ozdorovlenii vinograda ot virusnoj infekcii // Materialy regional'noj konferencii «Perspektivy vnedreniya sovremennyh biotekhnologicheskih razrabotok dlya povysheniya effektivnosti sel'skohozyajstvennogo proizvodstva». Stavropol', 2000. $72 \mathrm{~s}$.

5. Bowers J.E., Boursiquot J.M, This P., Chu K., Johansson H., Meredith C.P. Histological genetics parentage of Chardonnay, Camay, and other wine grapes of northeastern France. Science 285:1562-1565; 1999.

6. Stamp J.A., Meredith C.P. Somatic embryogenesis from leaves and anthers of grapevine // Scientia Hort. - 1988. - 35. - P. 235-250.

7. Zlenko V.A. Razmnozhenie ozdorovlennogo posadochnogo materiala vinograda // Sadovodstvo i vinogradarstvo Yuga Rossii. 2005. № 1. S. 21-23.

8. Medvedeva N.I., Polivara N.V., Troshin L.P. Osobennosti mikroklonal'nogo razmnozheniya introducentov i klonov vinograda // Nauch. zhurn. KubGAU. 2008. № 40 (06). S. 137-155.

9. Upadyshev M.T. Virusnye bolezni i sovremennye metody ozdorovleniya plodovyh i yagodnyh kul'tur: avtoref. dis. ... d-ra s.-h. nauk : 06.01.07 / Upadyshev Mihail Tar'evich. Moskva, 2011. $47 \mathrm{~s}$.

10. Gafurov R. Zelenaya revolyuciya po-russki // Agrohimiya NIOKR, himicheskij zhurnal. Dekabr' 2003-yanvar' 2004. S. 32-34.

11. Gafurov R.G. Stressprotektory-fitoregulyatory novogo pokoleniya - shans dlya innovacionnogo razvitiya v Respublike Tatarstan // Agriculture. 2008. № 2. R. 60-62.

12. Kotova Z.P., Gafurov R.G. Biologicheskaya effektivnost' stressprotektorov-fitoregulyatorov benzihol i etihol pri vyrashchivanii bezvirusnogo kartofelya v pochvenno-klimaticheskih usloviyah severnoj zony zemledeliya Rossii // Teoreticheskie i prikladnye problemy APK. 2020. № 3. S. 3-8. DOI 10/32935/2221-7312-2020-45-2-3-8

13. Bajguz A., Hayat S. Effect of brassinosteroids on the plant responses to environmental stresses // Plant Physiol. Biochem. 2009. V/47/ P. 1-8.

14. Mitteler R. Oxidative stress, antioxidants and stress tolerance // Trends Plant Sci. 2002.V.7, 405-409.

15. Ulmasov T., et al. IAA Proteins Re-press Expression of Reporter Genes Containing Natural and Highly Active Synthetic Auxin Response Elements // Plant Cell. 1997. Vol. 9. P. 1963-1971.

16 Savaldi-Goldstein S. et al. New auxin analogs with growth-promoting effects in intact plants reveal a chemical strategy to improvehormone delivery // PNAS. 2008. Vol. 105. No39. P. 15190-15195.

17. Reiser V., Raitt D.C., Saito H. Yeast osmosensor Sln1 and plant cytokinin receptor Cre1 respond to changes in turgor pressure // J. Cell Biol. - 2003. - 161. - P. 1035-1040.

18. Hayashi K. et al. Unrevealed structural requirements for auxin-like molecules by theoretical and experimental evidences // Phytochemistry. 2009. Vol. 70. Issue. 2. P. 190-197.

19. Metodicheskie rekomendacii po klonal'nomu mikrorazmnozheniyu vinograda / P.Ya. Golodriga [i dr.]. Yalta, 1986. 56 s.

20. Medvedeva N.I., Polivara N.V., Troshin L.P. Metodicheskie rekomendacii po mikroklonal'nomu razmnozheniyu vinograda in vitro // Nauchnyj zhurnal KubGau. 2010. № 65 (08). S. 314-326. 